\title{
The ht $\beta$ Gene Encodes a Novel CACCC Box-Binding Protein That Regulates T-Cell Receptor Gene Expression
}

\author{
YUKANG WANG, $\uparrow$ JOAN A. KOBORI, $\ddagger$ AND LEROY HOOD * $^{*}$ \\ Division of Biology 147-75, California Institute of Technology, Pasadena, California 91125
}

Received 11 January 1993/Returned for modification 31 March 1993/Accepted 3 June 1993

\begin{abstract}
A gene encoding a novel CACCC box-binding protein that binds to the promoter region of the human T-cell receptor (TCR) VB8.1 gene and the mouse TCR $\alpha$ gene silencer has been cloned. This gene, termed ht $\beta$, contains four zinc fingers of the class $\mathrm{Cys}_{2}-\mathrm{X}_{12}-\mathrm{His}_{2}$ that may be responsible for DNA binding and a highly negatively charged region that defines a putative transcriptional activation domain. Analysis of the expression of ht $\beta$ mRNA revealed similar expression levels and patterns in various cell lines. The bacterially expressed ht $\beta$ protein can bind to the CACCC box in both the human TCR VB8.1 gene promoter and the mouse TCR $\alpha$ gene silencer. The CACCC box is essential for efficient transcription of the VB8.1 promoter. Cotransfection with an ht $\beta$ expression plasmid and a reporter vector indicated that ht $\beta$ can activate human TCR VB8.1 gene transcription. ht $\beta$ also is able to counteract the silencing effect of the mouse TCR $\alpha$ gene silencer. The CACCC box has been found in almost all VB8.1 gene subfamily members and in both TCR $\alpha$ and $\beta$ gene enhancers in humans and mice. These results suggest that the CACCC box-binding protein may have an important regulatory function for $T C R$ gene expression in $\alpha \beta T$ cells versus $\gamma^{\delta} T$ cells.
\end{abstract}

$\mathrm{T}$ cells recognize antigens in the context of the self major histocompatibility complex via a clonally expressed T-cell receptor (TCR). The genes encoding TCR $\alpha, \beta, \gamma$, and $\delta$ chains have been characterized $(6-8,20,27,41,42,56)$. Each of the four TCR genes consists of multiple germ line gene segments that rearrange during $\mathrm{T}$-cell development to generate a mature T-cell population with clonally distributed receptors (29).

While the genomic organization of the four TCR genes has been well established, the regulation of the rearrangement and expression of these genes in the different $T$-cell subsets is relatively unknown. Recent studies have described transcriptional enhancers and silencers in human and murine TCR genes $(22,29,34,52,53)$ and two DNA-binding proteins that interact with the human TCR $\alpha$ gene enhancer (52). Studies aimed at examining the question of the tissue specificity of V $\beta$ promoters revealed that the human TCR V $\beta 8.1$ promoter is only active in T cells (9), implying that there are some T-cell-specific transcription factors that bind to the identified V $\beta 8.1$ promoter. A conserved decamer motif 10 to $40 \mathrm{bp}$ upstream of the TATA box has been identified in the murine VB promoters (1). This decamer also is present in the human VB8.1 promoter (45). Royer and Reinherz (40) have shown that there are four regions to which transcription factors bind in the 175-bp fragment of the human V $\beta 8.1$ promoter. One of the regions, a 21-bp GT-rich motif 72 bp upstream of the transcription initiation site, was only protected by nuclear extracts from $\mathrm{T}$-cell lines, not other cell lines, in a DNase footprinting study (40). The results suggest that $\mathrm{T}$-cell-specific transcription factors

\footnotetext{
* Corresponding author.

$\dagger$ Present address: Department of Cardiology, Children's Hospital, Harvard Medical School, Boston, MA 02115.

$\ddagger$ Present address: Immunotherapy Division, Baxter Biotech, Duarte, CA 91010.

$\S$ Present address: Department of Molecular Biotechnology, FJ20, University of Washington School of Medicine, Seattle, WA 98195.
}

may bind to the 21-bp GT-rich motif. There is a CACCC box that is reversely oriented in the 21-bp GT-rich region.

The CACCC box was first found in the $\beta$-globin gene promoter region and was required for efficient and accurate $\beta$-globin gene expression. A mutation in the CACCC box region strongly reduced transcription, suggesting that the CACCC box is an important promoter element (10). The CACCC box was observed not only in most members of the globin gene family but also in the erythroid transcription factor GATA-1 promoter (49), slow/cardiac troponin C gene enhancer (36), rat gastric $\mathrm{H}^{+} / \mathrm{K}^{+}$-ATPase $\beta$ gene promoter (32), glucocorticoid receptor gene promoter (19), and mouse immunoglobulin germ line $\mathrm{C} \boldsymbol{\gamma}_{1}$ gene promoter (55). CACCC box-binding proteins may function as important general transcription factors for gene expression. In addition to activating transcription by interacting with DNA sequences, the CACCC box-binding proteins interact with other transcription factors to carry out more functions $(19,44)$. Although the binding activities of multiple transcription factors have been well characterized, the isolation of a gene for a transcription factor that binds to the CACCC box has not been reported.

We now report the isolation and characterization of a novel cDNA gene encoding a CACCC box-binding protein, ht $\beta$, that recognizes the CACCC box in both the human TCR VB8.1 gene promoter and the mouse TCR $\alpha$ gene silencer. A functional analysis of the effect of the ht $\beta$ protein on TCR gene expression is presented, and the implication that this protein regulates the type of TCR ( $\alpha \beta$ or $\gamma \delta$ ) expressed on T cells is discussed.

\section{MATERIALS AND METHODS}

Oligonucleotides. The primers used for amplification of the mouse TCR $\alpha$ gene silencer I fragment (53) from mouse genomic clone TA4.1 (54) were as follows: primer 1, 5' CTCGAGCAACATGTGGGAAGA $3^{\prime}$; and primer $2,5^{\prime}$ CAGCTGTCTGTGTGATTCTTG $3^{\prime}$. The double-stranded probe used in the gel shift assays was produced by use of the oligonucleotides 5' GATCTGGGGGTGGGGTGGGGGTGG 
GGTGGGGGTGGGG $3^{\prime}$ and 5' GATCCCCCACCCCCAC CCCACCCCCACCCCACCCCCA 3'; the CACCC boxes are underlined. The oligonucleotides used for gel shift competition assays had two 17-mer GALA factor-binding sites (16): 5' CGGAGTACTGTCCTCCGCGGAGTACTGTCCTC CGCTGC $3^{\prime}$ and 5' GCAGCGGAGGACAGTACTCCGCG GAGGACAGTACTCCG 3'.

Library screening. A $\lambda$ gt11 cDNA library prepared with mRNA from phytohemagglutinin-stimulated human peripheral blood $T$ cells (Clontech) was screened by the method of Vinson et al. (50). Plaques $\left(2 \times 10^{6}\right)$ were screened at a density of $2 \times 10^{4}$ per filter after lytic infection of Escherichia coli Y1090. The probes used for screening the $\lambda$ gt11 cDNA library were generated from two complementary oligonucleotides corresponding to the sequence of the himan TCR VB8.1 promoter element from positions -72 to -92 (9): 5' AATTTTAAAGAAGTTGGGGGTGGTG 3' and 5' AATTCACCACCCCCAACTTCTTTAA 3'. The probes used in the screening were prepared by nick translation of size-selected, double-stranded catenated oligonucleotides with $\left[\alpha^{32} \mathrm{P}\right] \mathrm{dATP}$ and $\left[\alpha^{32} \mathrm{P}\right] \mathrm{dCTP}(33)$. The EcoRI inserts from positively selected plaques were subcloned into Bluescript-KSII (-) for sequence analysis by the dideoxy chain termination method for both strands (33). A $\lambda$ gt11 cDNA library made with Jurkat T-cell-line-derived mRNA by use of cDNA SYNTHESIS SYSTEM PLUS (Amersham) was constructed for isolating full-length ht $\beta$ cDNA.

Southern and Northern (RNA) analyses. Total genomic DNA was isolated from the human T-cell lymphoma-derived cell line Jurkat. DNA $(10 \mu \mathrm{g})$ was digested with EcoRI, HindIII, BamHI, and XbaI, resolved on an $0.8 \%$ agarose gel, and transferred to a nylon membrane (Zeta-Probe; Bio-Rad). Southern hybridization was carried out at $37^{\circ} \mathrm{C}$ overnight with $2.5 \times 10^{6} \mathrm{cpm}$ of denatured probe per $\mathrm{ml}(5 \times \mathrm{SSC}[1 \times$ SSC is $0.15 \mathrm{M} \mathrm{NaCl}$ plus $0.015 \mathrm{M}$ sodium citrate], $20 \mathrm{mM}$ sodium phosphate [pH 6.7], $10 \%$ dextran sulfate, $1 \%$ sodium dodecyl sulfate [SDS], $0.5 \%$ powdered milk, $100 \mu \mathrm{g}$ of denatured salmon sperm DNA per $\mathrm{ml}, 50 \%$ formamide). Washes were carried out three times in $0.1 \times$ SSC $-0.1 \%$ SDS at $65^{\circ} \mathrm{C}$ for $15 \mathrm{~min}$ each time.

The sources of the human RNAs were T-cell line Jurkat (ATCC CRL 8163), B-cell line Ramos (ATCC CRL 1596), monocyte line U-937 (ATCC CRL 1593), and HeLa cells (ATCC CCL2). RNAs were isolated from these cell lines by the guanidinium method (33), and poly(A) ${ }^{+}$RNAs were selected by oligo(dT)-cellulose chromatography (3). For Northern blot analysis, $10 \mu \mathrm{g}$ of poly(A) ${ }^{+}$RNA was resolved on a formaldehyde gel (33) and transferred to a nylon membrane (Zeta-Probe GT; Bio-Rad). Hybridization and washes were performed by the procedures recommended by the membrane manufacturer. RNA molecular weight markers were purchased from GIBCO-BRL.

Bacterial expression and DNase I footprinting assays. The bacteriophage $T 7$ expression system was used for the production of the ht $\beta$ protein (47). A DNA fragment containing a portion of the ht $\beta$ coding sequence, including the four zinc fingers, was created with $N d e I$ and $B c l$ I sites at the ends by use of appropriate oligonucleotides and polymerase chain reaction amplification. It was cloned into the $N d e I$ and BamHI sites of vector pET3a. This plasmid was transformed into strain BL21(DE3), which has the T7 RNA polymerase gene under lacUV5 promoter control. Transformed bacteria were induced with $1 \mathrm{mM}$ isopropyl- $\beta$-D-thiogalactopyranoside (IPTG) at an optical density at $600 \mathrm{~nm}$ of 0.7 for $4 \mathrm{~h}$ and harvested. Extracts were prepared by the method of Hoey and Levine (23), as modified by Treisman and Desplan (48).
The probes for DNase I footprinting were either RsaI$X b a I$ or Hinfl-NcoI fragments from the human V $\beta 8.1$ promoter region. They were isolated from cosmid H7.1 (45) and labeled at one end by the filling-in method with Klenow DNA polymerase (33). DNase I footprinting assays were performed as described by Galas and Schmitz (14). The binding reactions were carried out with 3 to $5 \mathrm{ng}$ of ${ }^{32} \mathrm{P}$ labeled DNA and $2 \mu \mathrm{g}$ of poly(I-C) (Boehringer Mannheim) in a 30- $\mu \mathrm{l}$ reaction volume for $20 \mathrm{~min}$ on ice. The composition of the binding reaction mixture was as described by Fan and Maniatis (12). After binding was accomplished, $4 \mu \mathrm{l}$ of $100 \mathrm{mM} \mathrm{MgCl} 2-150 \mathrm{mM} \mathrm{CaCl}_{2}$ was added to the reaction mixture, and then $1 \mu \mathrm{l}$ of freshly diluted DNase I (Worthington) at a final concentration of $25 \mu \mathrm{g} / \mathrm{ml}$ was added. DNase I digestion was stopped after $1 \mathrm{~min}$ on ice by the addition of the stop solution described by Hoey and Levine (23). The samples were extracted twice with phenol-chloroform (1:1) and once with chloroform, ethanol precipitated, and electrophoresed in a $6 \%$ polyacrylamide $-8 \mathrm{M}$ urea gel.

Plasmid construction. (i) Expression plasmids. The fulllength ht $\beta$ cDNA was subcloned into the EcoRI site of pSG5, a eukaryotic expression vector (Stratagene) in which the full-length ht $\beta$ cDNA is under the control of the simian virus 40 (SV40) early promoter.

(ii) Reporter plasmids. The human V $\beta 8.1$ promoter region (9) at various lengths was subcloned into the pCAT enhancer plasmid (Promega), which has a chloramphenicol acetyltransferase (CAT) gene and an SV40 enhancer but lacks the promoter. For pVB8.1CAT, the MseI-BstNI (positions -91 to +17 ) fragment of human V $\beta 8.1$ was blunt ended with Klenow DNA polymerase and then ligated to the XbaIdigested, blunt-ended pCAT enhancer plasmid. Plasmid $\mathrm{p} \Delta \mathrm{V} \beta 8.1 \mathrm{CAT}$ was constructed by subcloning a blunt-ended HaeIII fragment (positions -71 to +14 ) into the pCAT enhancer plasmid. The oligonucleotide containing five repeats of CACCC was ligated to HindIII-digested, bluntended $\mathrm{p} \triangle \mathrm{V} \beta 8.1 \mathrm{CAT}$, placing the five repeats of CACCC upstream of the V $\beta 8.1$ promoter HaeIII fragment. The resulting plasmid was named pO $\Delta \mathrm{V} \beta 8.1 \mathrm{CAT}$.

The mouse TCR $\alpha$ gene silencer I fragment (53) was made by PCR amplification of mouse genomic clone TA4.1 (54) and confirmed by DNA sequence analysis. The 309-bp mouse TCR silencer I fragment was ligated to either BglIIor XbaI-cleaved, blunt-ended pCAT control plasmid (Promega), which has an SV40 promoter, an SV40 enhancer, and a CAT gene. The mouse TCR $\alpha$ gene silencer was placed either upstream of the SV40 early promoter when digestion was done with BglII (named pControl sil 5') or downstream of the SV40 enhancer when digestion was done with $\mathrm{XbaI}$ (named pControl sil). All the plasmid constructs were confirmed by DNA sequence analysis.

Nuclear extract preparation and gel shift assays. HeLa cells were grown in Dulbecco modified essential medium (DMEM) containing $10 \%$ fetal calf serum (FCS). U-937, Ramos, and Jurkat cells were grown in RPMI 1640 medium containing $10 \%$ FCS. Cells were harvested in the log phase, and nuclear extracts were prepared as described by Schreiber et al. (43). Gel shift assays were performed under the conditions described by Fan and Maniatis (12). Nuclear extracts $(10 \mu \mathrm{g})$ were incubated with $2.5 \mathrm{ng}$ of ${ }^{32} \mathrm{P}$-labeled probe and $2.5 \mu \mathrm{g}$ of poly(I-C) on ice for $20 \mathrm{~min}$. The reaction mixtures were loaded on a $6 \%$ polyacrylamide- $0.5 \times$ TBE (Tris-borateEDTA buffer) gel.

Transfection. HeLa cells were transfected with plasmid DNA by use of liposomes (2). In brief, exponentially growing cells were plated in six-well tissue culture dishes at $5 \times$ 

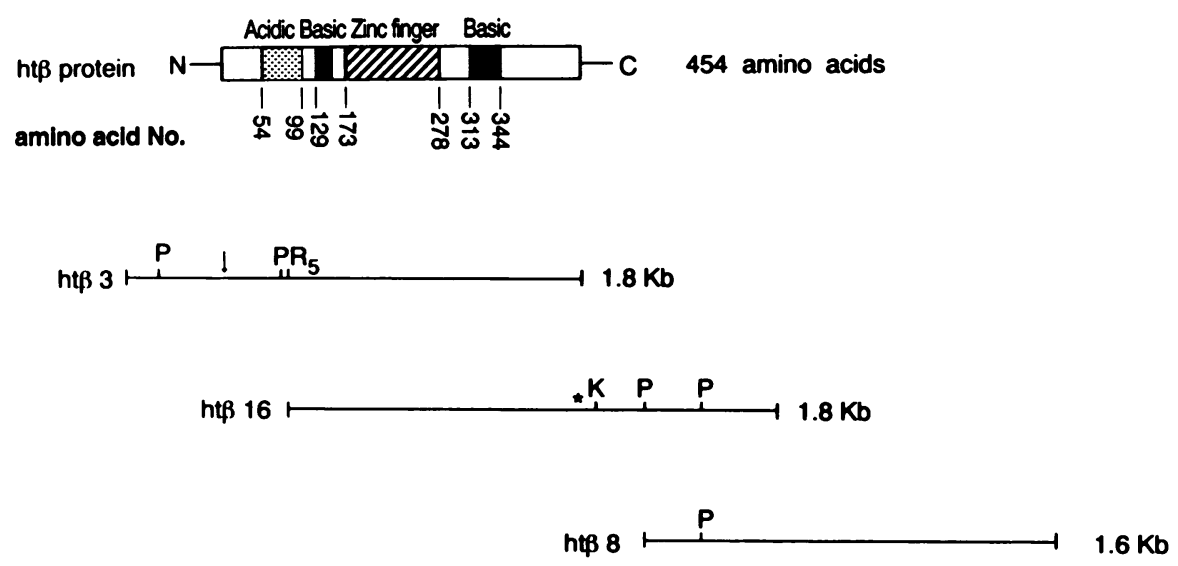

$1 \mathrm{~Kb}$

FIG. 1. cDNAs and predicted protein structure of ht $\beta$. The overlapping cDNAs ht $\beta 16$ and ht $\beta 8$ were isolated from a human peripheral T-cell cDNA library, and cDNA ht $\beta 3$ was isolated from a Jurkat T-cell-line cDNA library. Restriction enzyme sites: K, KpnI; R5, EcoRV; $P$, PstI. A schematic diagram of the predicted ht $\beta$ protein structure is shown, with three cDNA clones aligned with the protein structure. The interesting motifs in the protein are indicated. The vertical arrow indicates the translation start site, and the asterisk indicates the stop codon.

$10^{5}$ cells per well and grown overnight. Plasmid DNA was mixed with $20 \mu \mathrm{g}$ of Lipofectin reagent (GIBCO-BRL) in 1 $\mathrm{ml}$ of serum-free DMEM. One milliliter of the DNA-liposome complex was added directly to the cells. Incubation for $3 \mathrm{~h}$ at $37^{\circ} \mathrm{C}$ was followed by the addition of $1 \mathrm{ml}$ of DMEM containing $20 \%$ FCS. Cells were harvested $48 \mathrm{~h}$ after transfection for CAT assays.

The DEAE-dextran method (13) was used for the transfection of Jurkat cells. Cells $\left(5 \times 10^{6}\right)$ were incubated in $1 \mathrm{ml}$ of Tris-buffered saline containing plasmid DNA and $500 \mu \mathrm{g}$ of DEAE-dextran (Promega) per $\mathrm{ml}$ for $30 \mathrm{~min}$ at room temperature. Cells were then washed with Tris-buffered saline and incubated in $20 \mathrm{ml}$ of RPMI 1640 medium containing 10\% FCS for $48 \mathrm{~h}$. As a control for differences in transfection efficiencies, 0.5 to $1 \mu \mathrm{g}$ of a $\beta$-galactosidase gene-containing plasmid (pCMV-lacZ; a kind gift from Ebrahim Zandi, Department of Chemistry and Chemical Engineering, California Institute of Technology) was included in each transfection.

CAT assays and $\beta$-galactosidase assays. Cells (HeLa) were harvested by scraping with a rubber policeman, centrifuged, and then washed once with phosphate-buffered saline. Cells were resuspended in $100 \mu$ l of $0.25 \mathrm{M}$ Tris- $\mathrm{HCl}(\mathrm{pH} \mathrm{7.4)}$ and subjected to three cycles of freeze-thaw lysis in liquid nitrogen. The subsequent assays were done as described by Gorman et al. (17) with $0.2 \mu \mathrm{Ci}$ of $\left[{ }^{14} \mathrm{C}\right]$ chloramphenicol (Amersham) and $25 \mu \mathrm{g}$ of acetyl coenzyme A (Sigma) for each reaction. The acetylated and nonacetylated forms of chloramphenicol were excised from the thin-layer chromatographs, and the amount of radioactivity was determined by liquid scintillation counting. The $\beta$-galactosidase assays were done as described previously (33) with $o$-nitrophenyl$\beta$-D-galactopyranoside (Sigma) as a substrate. The amounts of cell extracts used for CAT assays were optimized on the basis of $\beta$-galactosidase assay results.

Nucleotide sequence accession number. The sequence reported in this paper has been deposited in the GenBank data base under accession number $\mathbf{L} 04282$.

\section{RESULTS}

Isolation and DNA sequence of the ht $\beta$ gene. A DNA probe containing the sequence from positions -72 to -92 of the human V $\beta 8.1$ promoter was used to screen a $\lambda g t 11$ expression library constructed from T-cell-derived mRNA. The screening of $2 \times 10^{6}$ plaques yielded two positive clones. One of the clones, ht $\beta 16$, contained a $1.8-\mathrm{kb}$ insert that was subcloned into Bluescript-KSII (-) for sequence analysis. Using the 1.8-kb ht $\beta 16$ insert to rescreen the same library, we found a clone, ht $\beta 8$, that overlaps the $3^{\prime}$ sequence of ht $\beta 16$. Another clone, ht $\beta 3$, which has a 1.8-kb insert, overlaps for $1 \mathrm{~kb}$ the $5^{\prime}$ sequence of ht $\beta 16$ (Fig. 1). This clone was isolated from a $\lambda$ gt11 library made with Jurkat T-cellline-derived mRNA. Southern blotting of Jurkat T-cell-line genomic DNA digested with EcoRI, BamHI, HindIII, and $X b a I$ and probed with the $1.8-\mathrm{kb}$ ht $\beta 16$ fragment indicated a dominant single band, although some faint bands appeared upon longer exposure (data not shown).

The DNA sequence of ht $\beta$ was determined (Fig. 2). The sequence predicts a long open reading frame of 1,362 nucleotides that is terminated by six in-frame stop codons. The $3^{\prime}$-untranslated region is 666 nucleotides long. The poly(A) site was not identified. The nucleotide sequence of the open reading frame was translated into its corresponding 454amino-acid sequence. The molecular mass of the ht $\beta$ protein encoded by the full-length mRNA is approximately $49 \mathrm{kDa}$. Inspection of the amino acid sequence shown in Fig. 2 indicates that the $h t \beta$ protein has four tandem zinc fingers near the middle of the open reading frame. The first two finger motifs have the general form Cys- $\mathrm{X}_{2}-\mathrm{Cys}-\mathrm{X}_{3}-\mathrm{Phe}-\mathrm{X}_{5}-$ Leu- $X_{2}-$ His- $X_{3}-$ His. The third and fourth fingers have the modified forms Cys- $\mathrm{X}_{2}-\mathrm{Cys}-\mathrm{X}_{8}-\mathrm{His}-\mathrm{X}_{3}-\mathrm{His}$ and Cys- $\mathrm{X}_{2}-\mathrm{Cys}-$ $X_{3}-$ Phe- $X_{6}-$ Leu- $X_{1}-$ His- $X_{4}-$ His, respectively. At the aminoterminal side of the zinc finger region is a highly acidic segment (residues 54 to 99) that has the potential to form an $\alpha$-helix. This segment has a net charge of -12 . Other features of interest in the ht $\beta$ sequence include a highly basic segment (residues 129 to 153) at the amino-terminal side of 
1 GAATTCCGGAGAAAGGCGCAGGGGTGGGAGCTGTTGCCGAAGCTGCCACAGCAAAAGTTC

61 TCCCCСCTCCCCCCTTCCCCTCCTCTCAAGGCCCCTAGAAAGGTTGGAGCTGCEGGCCCT 120

121 GCAGTCGgTGACCGCTGACGACTTCGGCCGCGCCCGCGGATAGAGGGAGGAATCAGCAGC 180

181 TTGGAAATCAAGCACGTGATCTGGCGGGATGGCGTTTGCCTAACGTATTTAATGGAGGA 240

241 ATCGGATGGCATAAGTGATTAAGGTGGTATTGAGGATTTCTGAAGCCTATGAAAGGTAGA 300

301 AACTCAACCATGATTTCTTTTTCAACTCTACAGCATTCCTTTCCTTGAAGTCTTCGTTTT 360

361 TACCTTAGTCTCGGGCAGTTATACTTAAGCATGAACATTGACGACAAACTGGAAGGATTG 420

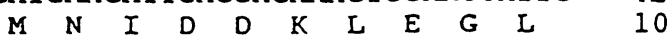

421 TTTCTTAAATGTGGCGGCATAGACGAAATGCAGTCTTCCAGGACAATGGTTGTAATGGGT 480 $\begin{array}{lllllllllllllllllllll}F & L & K & C & G & G & I & D & E & M & Q & S & S & R & T & M & V & V & M & G & 30\end{array}$

481 GGAGTGTCTGGCCAGTCTACTGTGTCTGGAGAGCTACAGGATTCAGTACTTCAAGATCGA 540 $\begin{array}{lllllllllllllllllllllll}G & V & S & G & Q & S & T & V & S & G & E & L & Q & D & S & V & L & Q & D & R & & 50\end{array}$

541 AGTATGCCTCACCAGGAGATCCTTGCTGCAGATGAAGTGTTACAAGAAAGTGAAATGAGA 600 $\begin{array}{llllllllllllllllllll}S & M & P & H & Q & \text { E } & I & L & A & A & \text { (D) (E) } V & L & Q & \text { (E) } S & \text { (E) } & M & \text { (R) } & 70\end{array}$

601 CAACAGGATATGATATCACATGATGAACTCATGGTCCATGAGGAGACAGTGAAAAATGAT 660

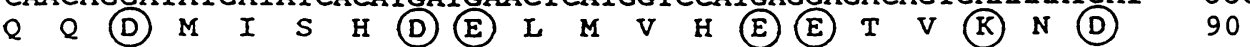

661 GAAGAGCAGATGGAAACACATGAAAGACTTCCTCAAGGACTACAGTATGCACTTAATGTC 720 (E) (E) $Q \quad M \quad$ (E) $T$ T

721 CCTATAAGCGTAAAGCAGGAAATTACTTTMATGATGTATCTGAGCAACTGATGAGAGAC 780

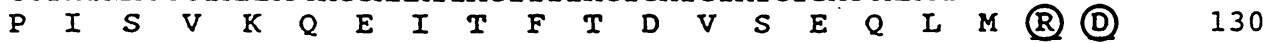

781 AAAAAACAAATCAGAGAGCCAGTAGACTTACAGAAAAAGAAGAAGCGGAAACAACGTTCT 840

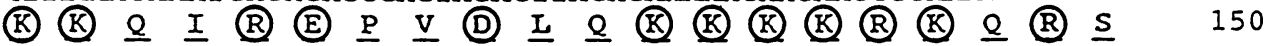

841 CCCGCAAAAATCCTTACAATAAATGAGGATGGATCACTTGGTTTGAAAACCCCTAAATCT 900

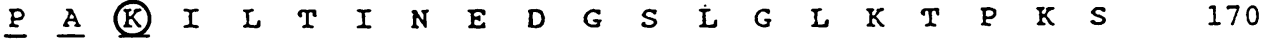

901 CACGTTTGTGAGCACTGCAATGCTGCCTTTAGAACGAACTATCACTTACAGAGACATGTC 960 $\begin{array}{llllllllllllllllllllll}H & \mathrm{~V} & \mathrm{C} & \mathrm{E} & \mathrm{H} & \mathrm{C} & \mathrm{N} & \mathrm{A} & \mathrm{A} & \mathrm{F} & \mathrm{R} & \mathrm{T} & \mathrm{N} & \mathrm{Y} & \mathrm{H} & \mathrm{L} & \mathrm{Q} & \mathrm{R} & \mathrm{H} & \mathrm{V} & & 190\end{array}$

961 TTCATTCATACAGGTGAAAAACCATTTCAATGTAGTCAATGTGACATGCGTTTCATACAG 1020 $\begin{array}{lllllllllllllllllllllll}F & I & H & T & G & E & K & P & F & Q & C & S & Q & C & D & M & R & F & I & Q & & 210\end{array}$

1021 AAGTACCTGCTTCAGAGACATGAGAAGATTCATACTGGTGAAAAACCATTTCGCTGTGAT 1080 $\begin{array}{llllllllllllllllllllllll}K & \mathrm{Y} & \mathrm{L} & \mathrm{L} & \mathrm{Q} & \mathrm{R} & \mathrm{H} & \mathrm{E} & \mathrm{K} & \mathrm{I} & \mathrm{H} & \mathrm{T} & \mathrm{G} & \mathrm{E} & \mathrm{K} & \mathrm{P} & \mathrm{F} & \mathrm{R} & \mathrm{C} & \mathrm{D} & 230\end{array}$

1081 GAATGTGGTATGAGATCCATACAAAAATATCATATGGAAAGGCATAAGAGAACTCATAGT 1140 $\begin{array}{lllllllllllllllllllllll}E & C & G & M & R & S & I & Q & K & X & H & M & E & R & H & K & R & T & H & S & 250\end{array}$

1141 GGAGAAAAACCTTACCAGTGTGAATACTGTTTACAGTATTTTTCCAGAACAGATCGTGTA 1200 $\begin{array}{lllllllllllllllllllll}G & E & K & P & Y & Q & C & E & Y & C & L & Q & Y & F & S & R & T & D & R & V & 270\end{array}$

1201 TTGAAACATAAACGTATTGGCCATGAAAATCATGACA,LAAAACTAAATACATGTGCCATG 1260 $\begin{array}{llllllllllllllllllllllll}L & K & H & K & R & I & G & H & E & N & H & D & K & K & I & N & T & C & A & M & 290\end{array}$

FIG. 2. DNA sequence and predicted amino acid sequence of ht $\beta$. The amino acid sequence predicted from the longest reading frame of $h t \beta$ is shown. The zinc finger motifs are indicated by underlining; the highly acidic segment that occurs amino terminal to the zinc fingers is denoted by double underlining, and the charged amino acids are circled. Basic segments that are located before and after the zinc fingers are indicated by broken underlining, and the charged amino acids are circled. The six in-frame stop codons begin at the asterisk.

the zinc finger region and another basic segment (residues 314 to 344 ) downstream of the fingers.

ht $\beta$ encodes a protein that can bind to the CACCC boxes of the human TCR VB8.1 gene promoter and the mouse TCR $\alpha$ gene silencer. A fragment of ht $\beta$ (residues 81 to 445 ) containing most of the coding region was expressed in $E$. coli. A portion of the acidic region is missing from the expressed protein, but all four zinc fingers are present. Plasmid pET3a- $\mathrm{ht} \beta$ encodes a 40-kDa protein composed of 365 amino acids. The deduced molecular weight of this protein is the same as the size determined by SDS-polyacrylamide gel analysis (data not shown). Crude lysates of $E$. coli BL21(DE3) containing pET3a-ht $\beta$ were tested for DNA-binding activity by DNase I footprinting with the human TCR VB8.1 promoter element. Extracts prepared from BL21(DE3)(pET3aht $\beta$ ) but not BL21(DE3)(pET3a) were found to protect 


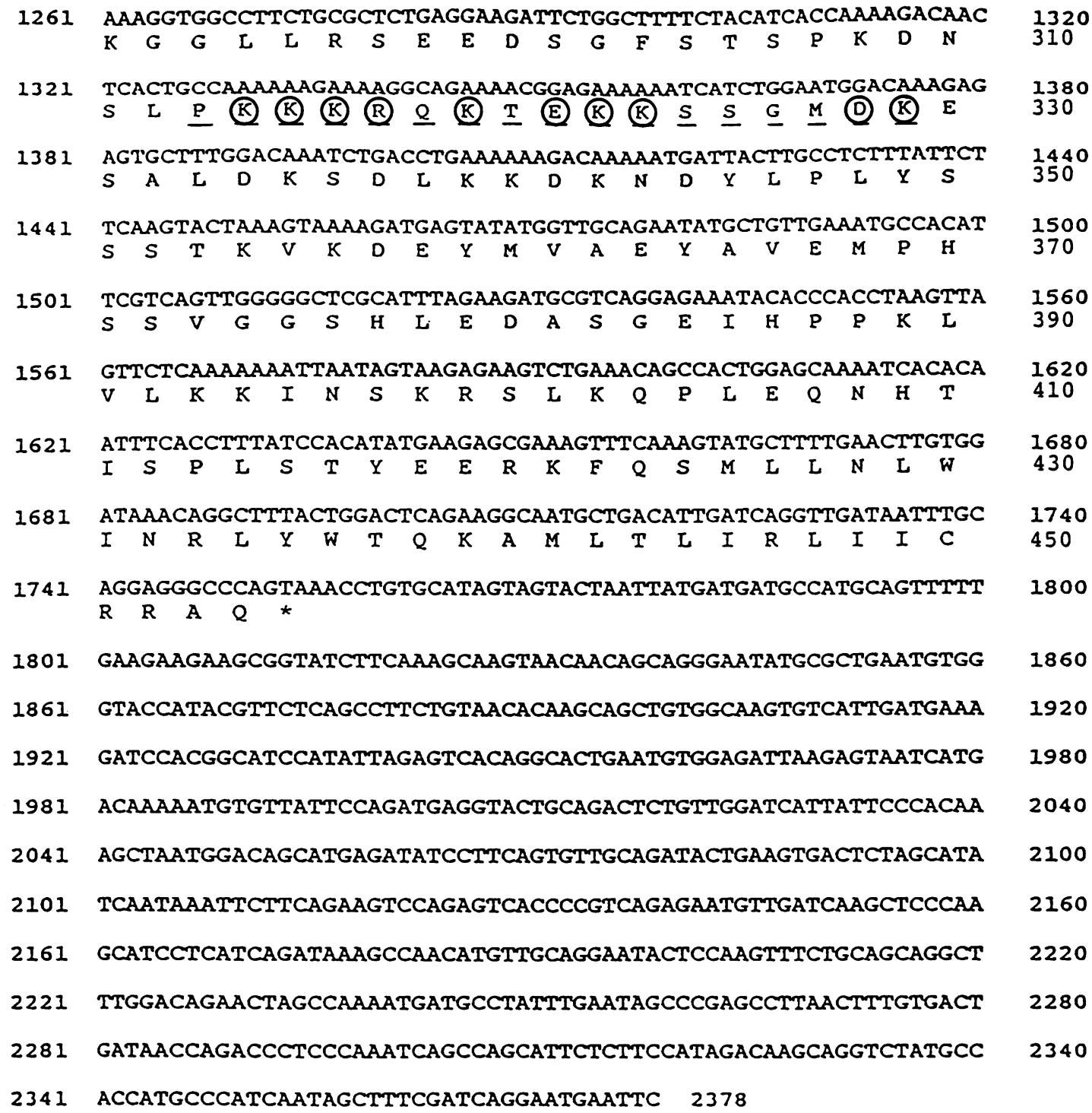
FIG. 2-Continued.

nucleotides GAAGTTGGGGGTGGTG of the VB8.1 promoter from digestion by DNase I (data not shown). The DNase I footprinting assay was done with both coding and noncoding strands of the V $\beta 8.1$ promoter, and the protected regions were about the same. The 365 amino acid residues of the truncated ht $\beta$ protein that include the four zinc fingers are sufficient for sequence-specific binding of the ht $\beta$ protein to DNA.

The mouse TCR $\alpha$ gene silencer I sequence has a region (53) that is highly similar to the ht $\beta$-binding site in the TCR VB8.1 gene promoter. Crude lysates of $E$. coli BL21(DE3) containing pET3a-ht $\beta$ were tested for DNA-binding activity by DNase I footprinting with the mouse TCR $\alpha$ gene silencer I fragment. Extracts prepared from BL21(DE3)(pET3a-ht $\beta$ ) protected the 163- to 193-bp region of the mouse TCR $\alpha$ gene silencer from digestion by DNase I (data not shown).

When the ht $\beta$-binding sites in both the human TCR VB8.1 gene promoter and mouse TCR $\alpha$ gene silencer I were compared (Fig. 3), a consensus sequence, TGGGGGTGG, which contains the complement of the well-known CACCC box in the center, was found (10). For determination of whether only this CACCC motif is necessary for ht $\beta$ protein binding, double-stranded oligonucleotides containing five repeats of the CACCC box were synthesized, annealed, and labeled with ${ }^{32} \mathrm{P}$ as probes for a gel shift analysis. The probes formed DNA-protein complexes with extracts prepared from BL21(DE3)(pET3a-htß) but not BL21(DE3)(pET3a) (Fig. 4). This result clearly shows that CACCC is the core sequence for ht $\beta$ binding. Very likely ht $\beta$ is one of the long-sought CACCC box-binding proteins.

In addition, nuclear extracts from $\mathrm{HeLa}$ cells, U-937 monocytes, Ramos B cells, and Jurkat $T$ cells were tested with the same probes containing five CACCC boxes in a gel shift assay. Four common bands were visible with all nuclear extracts tested, and an additional, fast-moving band was seen with extracts from HeLa cells (data not shown). For demonstration of the specificity of binding to the CACCC box, excess amounts of unlabeled CACCC-containing oligonucleotides or GAL4-binding-site-containing oligonucleotides with no homology to the CACCC box were added to 


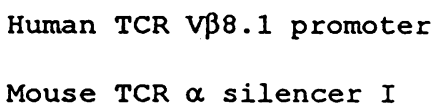

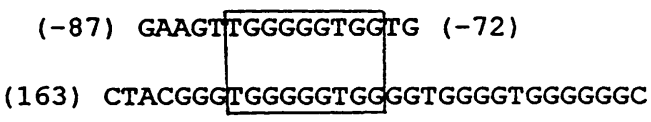

(193)

FIG. 3. Comparison of the ht $\beta$-binding sites in the human TCR V $\beta 8.1$ gene promoter (positions -87 to -72 ) and mouse TCR $\alpha$ gene silencer I (positions 163 to 193). The homologous regions in the binding sites are boxed.

the reaction mixture of ${ }^{32} \mathrm{P}$-labeled CACCC-containing oligonucleotides and either HeLa cell or Jurkat cell nuclear extracts. All bands in the HeLa cell extract assay were efficiently inhibited through competition by 20 to $50 \mathrm{ng}$ of a cold CACCC-containing fragment but not by $50 \mathrm{ng}$ of a GAL4-binding-site-containing oligonucleotide. In Jurkat $T$ cells, three bands were inhibited through competition by a 20-fold molar excess of a specific CACCC-containing fragment (data not shown). A rabbit polyclonal anti-ht $\beta$ antibody did not successfully compete for binding, although the antibody has been shown to bind $E$. coli-expressed ht $\beta$ protein by Western blot (immunoblot) analysis (data not shown).

Expression of ht $\beta$ mRNA. For studying the pattern of

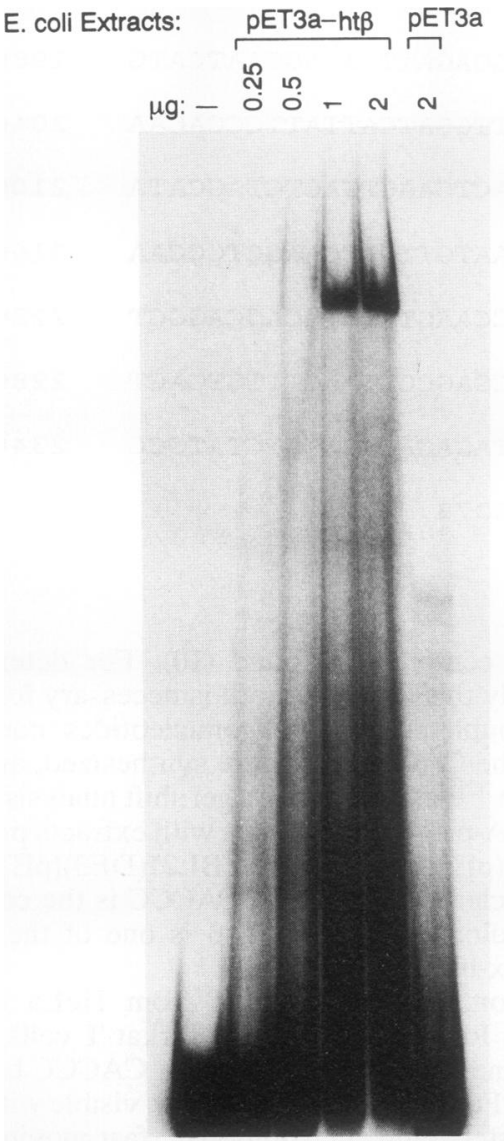

FIG. 4. Gel shift assay of synthetic oligonucleotides containing five repeats of the CACCC box with protein extracts from bacteria containing plasmid pET3a-ht $\beta$. From left to right, lanes contained 0 , $0.25,0.5,1$, and $2 \mu \mathrm{g}$ of protein extracts from bacteria containing pET3a-ht $\beta$. The rightmost lane contained $2 \mu \mathrm{g}$ of protein extracts from bacteria containing only pET3a, the vector. expression of the ht $\beta$ gene, RNA was isolated from various tissue culture cell lines. Poly(A) ${ }^{+}$RNAs were selected by oligo(dT)-cellulose chromatography and detected by Northern blot analysis with the 1.8 -kb segment of ht $\beta 16$ as a probe. As shown in Fig. 5, three RNA species, with estimated sizes of $4.2,7.6$, and $8.6 \mathrm{~kb}$, were detected. The same blot was rehybridized with the EcoRI-EcoRV fragment of ht $\beta 3$, which does not contain the zinc finger region, and again three RNA species with the same sizes as shown in Fig. 5 were seen. For controlling for potential variations in the levels of RNA electrophoresed, the blot was rehybridized with a human $\beta$-actin probe. Comparable levels of hybridized RNA were observed with the $\beta$-actin probe, indicating that the levels of expression of ht $\beta$ are not significantly different in the four cell lines tested.

ht $\beta$ activates human TCR VB8.1 gene expression and antagonizes the function of the mouse TCR $\alpha$ gene silencer.

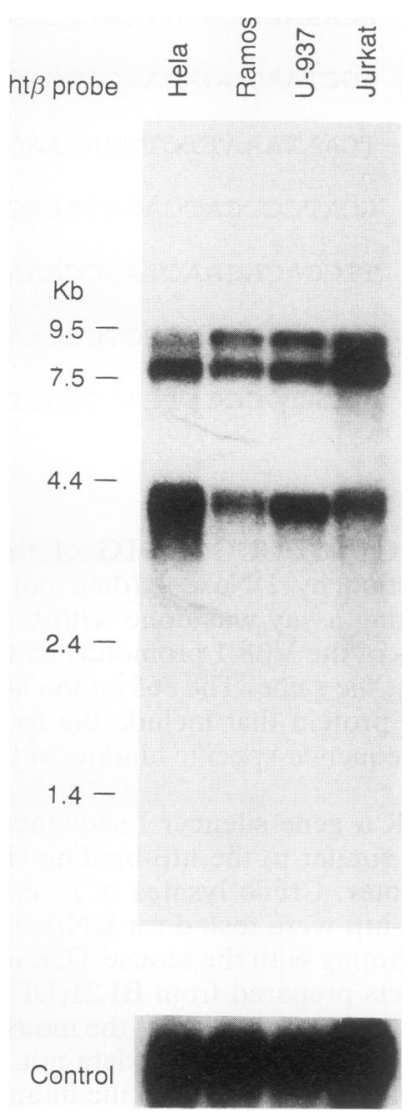

FIG. 5. Northern blot analysis of poly(A) ${ }^{+}$RNAs from various cell lines. Poly $(A)^{+}$RNAs were loaded at $10 \mu \mathrm{g}$ in each lane. The blot was hybridized with a labeled 1.8-kb insert of ht $\beta 16$. 


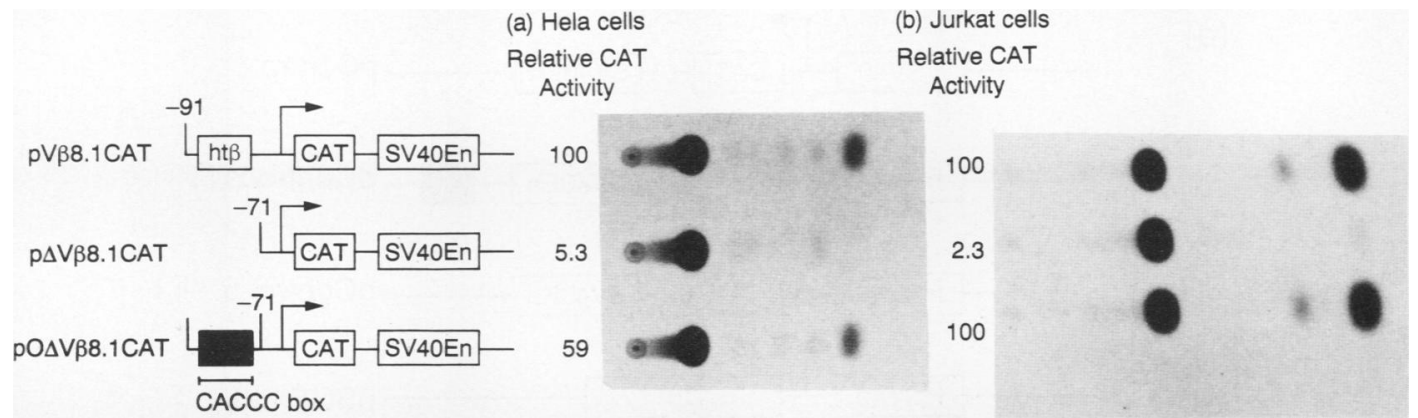

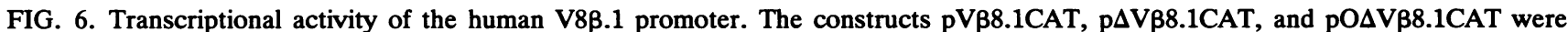
described in Materials and Methods. The transcription start site of the SV40 promoter is indicated by an arrow. En, enhancer. (a) HeLa cells were transfected with $2 \mu \mathrm{g}$ of various V $\beta 8.1$ promoter constructs and $0.5 \mu \mathrm{g}$ of pCMV-lacZ by the liposome method. (b) Jurkat cells were transfected with $5 \mu \mathrm{g}$ of various V $\beta 8.1$ promoter constructs and $1 \mu \mathrm{g}$ of pCMV-lacZ by the DEAE-dextran method. In both cases, the amounts of cell extracts used in the CAT assay were optimized on the basis of $\beta$-galactosidase activities.

For studying the importance of the CACCC box in TCR VB8.1 transcription, various V $\beta 8.1$ promoter constructs were made and analyzed for expression in both HeLa and Jurkat T cells (Fig. 6). Plasmid pVB8.1CAT, which contains the natural CACCC box in the VB8.1 gene promoter, had significant CAT activity. However, for $\mathrm{p} \triangle \mathrm{V} \beta 8.1 \mathrm{CAT}$, which has a deletion of the upstream CACCC, CAT activity was dramatically decreased, to about 5 and $2 \%$ of the transcriptional activities of pVB8.1CAT in HeLa and Jurkat cells, respectively. The addition of five repeats of the CACCC box upstream of the V $\beta 8.1$ promoter in plasmid $\mathrm{p} \Delta \mathrm{V} \beta 8.1 \mathrm{CAT}$ increased CAT activity greatly; 59 and $100 \%$ of the transcriptional activities of pVB8.1CAT were restored in HeLa and Jurkat cells, respectively.

For studying the regulatory function of the ht $\beta$ protein, the full-length ht $\beta$ cDNA was subcloned into pSG5, a eukaryotic gene expression vector, under the control of the SV40 early promoter. The expression plasmids were cotransfected into HeLa cells with plasmid pVB8.1CAT, which has a VB8.1 promoter containing the CACCC box followed by a CAT gene. Because of the presence of endogenous ht $\beta$ protein, cotransfection with the ht $\beta$ expression plasmid and reporter plasmid pVB8.1CAT resulted in a modest increase in CAT activity, compared with that in the transfection with the reporter plasmid alone. The twofold increase in CAT activity was very reproducible (Fig. 7). The ht $\beta$ protein was able to activate transcription of the human V $\beta 8.1$ gene.

Besides binding to the V $\beta 8.1$ promoter, ht $\beta$ also can bind to another TCR regulatory sequence, mouse TCR $\alpha$ gene silencer I. The regulation of mouse TCR $\alpha$ gene silencer I by the ht $\beta$ protein was investigated. The presence of mouse TCR $\alpha$ gene silencer I downstream of the SV40 enhancer (pControl sil) and upstream of the SV40 promoter (pControl sil $5^{\prime}$ ) resulted in decreased transcription (approximately 40 and $67 \%$, respectively) (Fig. 8), while cotransfection of pControl sil or pControl sil $5^{\prime}$ with pSG5-ht $\beta$ restored transcription to 97 or $61 \%$, respectively. These results indicate that ht $\beta$ can reverse the silencing function of the mouse $\alpha$ gene silencer.

\section{DISCUSSION}

An oligonucleotide probe that corresponds to the sequence of the human TCR VB8.1 promoter element from positions -72 to -92 and that contains a CACCC box was used to isolate a cDNA clone from a $\lambda$ gt11 expression library prepared from human peripheral T-cell mRNA. This cDNA hybridizes to three mRNA species present in a variety of cell types, including HeLa cells, U-937 monocytes, Ramos B cells, and Jurkat $T$ cells. The three mRNA species may reflect alternative mRNA splicing of the ht $\beta$ gene, or the 7.6and 8.6-kb mRNA species could be unspliced forms of the 4.2-kb mRNA. Other cDNA segments containing overlapping sequences were isolated from the above-described library or a library prepared from Jurkat-cell-line-derived RNA. The sequence of a composite cDNA of $3.6 \mathrm{~kb}$ was partially determined. Translation of this sequence revealed a long open reading frame of 454 amino acid residues encoding a protein of approximately $49 \mathrm{kDa}$. ht $\beta$ may be a single-copy

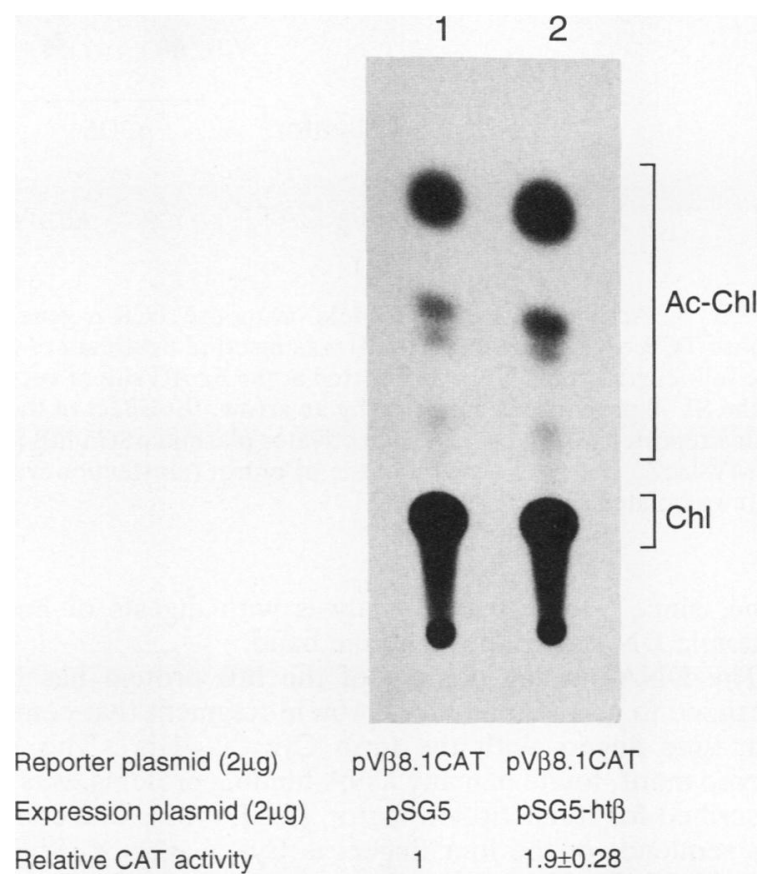

FIG. 7. Activity of the ht $\beta$ protein on the human VB8.1 promoter. Two micrograms of reporter plasmid pVB8.1CAT was cotransfected with $2 \mu \mathrm{g}$ of expression plasmid pSG5 (lane 1) or pSG5-htB (lane 2) into HeLa cells by the liposome method (15). An internal control (pCMV-lacZ) $(0.5 \mu \mathrm{g})$ was included in each transfection. The relative CAT activities were calculated. Ac-Chl, acetylated chloramphenicol. 
(a)
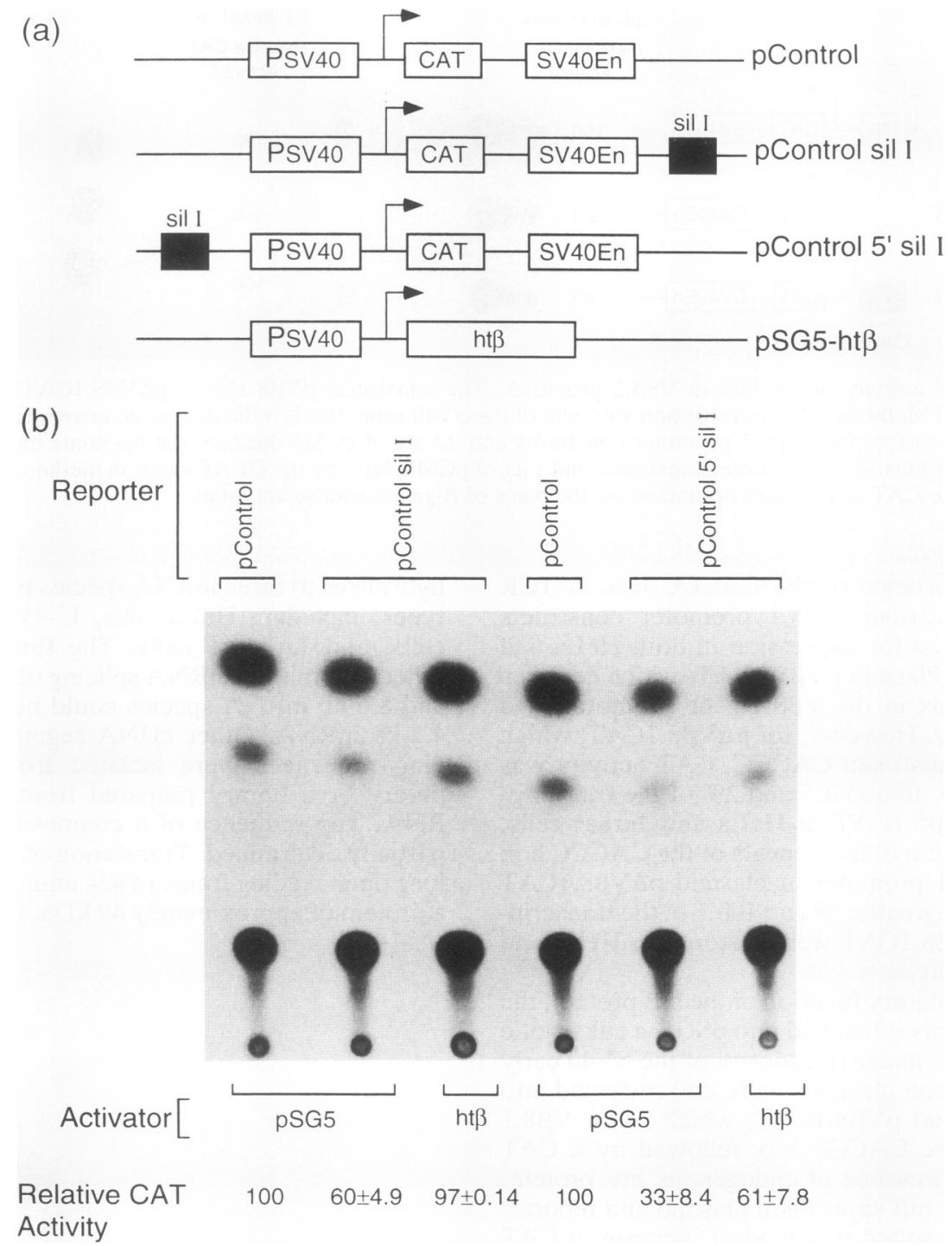

FIG. 8. Activity of the ht $\beta$ protein on mouse TCR $\alpha$ gene silencer I. (a) Schematic organization of reporter and expression plasmids. Mouse TCR $\alpha$ gene silencer I (sil I) was inserted upstream of the SV40 promoter (PSV40) or downstream of the SV40 enhancer (SV40En). The full-length ht $\beta$ cDNA was inserted at the EcoRI site of vector pSG5, which contains an SV40 early promoter. The transcription start site of the SV40 promoter is indicated by an arrow. (b) Effect of the ht $\beta$ protein on mouse TCR $\alpha$ gene silencer I. HeLa cells were cotransfected with a reporter plasmid $(2 \mu \mathrm{g})$ and activator plasmid pSG5-ht $\beta(2 \mu \mathrm{g})$ or parental vector pSG5, together with $0.5 \mu \mathrm{g}$ of internal control plasmid pCMV-lacZ. The CAT activity of the pControl transfection was considered 100\%, and the relative CAT activities of the other transfections were calculated.

gene, since Southern blot analysis with digests of human genomic DNA revealed only one band.

The DNA-binding domain of the ht $\beta$ protein has been localized to a 118-amino-acid protein fragment that contains four zinc fingers with the form $\mathrm{Cys}_{2}-\mathrm{X}_{12}-\mathrm{His}_{2}$. This conserved motif, found in many DNA-binding proteins, was first described for transcription factor TFIIIA (35). The consensus sequence of the four fingers is Cys- $\mathrm{X}_{2}-\mathrm{Cys}-\mathrm{X}_{3}-\mathrm{Phe}-\mathrm{X}_{5}-$ Leu- $X_{2}-$ His- $X_{3}$-His. Sequence analysis of the ht $\beta$ protein suggests that the negatively charged segment that can form an $\alpha$-helical structure may be involved in transcriptional activation, as described for the yeast factors GCN4 and GALA $(24,31,38)$, AP- 1 or Jun transcription factors $(5,46)$, and the immunoglobulin heavy-chain enhancer-binding protein (4). The two basic segments may be involved in the nuclear localization of $\mathrm{ht} \beta$, as proposed by Dingwall and Laskey (11).

The specific binding of the ht $\beta$ protein to the human TCR VB8.1 promoter was shown by DNase I footprinting. Since the portion of the ht $\beta$ protein that includes the zinc finger region is able to bind DNA specifically, the zinc finger region is most likely responsible for DNA binding. The binding site contains approximately 16 nucleotides, GAAGTTGGG GGTGGTG. In addition to binding to the human TCR V $\beta 8.1$ promoter, ht $\beta$ also binds to another $T$-cell regulatory sequence, mouse TCR $\alpha$ gene silencer I (Fig. 3). A comparison of the binding sites in both the V $\beta 8.1$ promoter and $\alpha$ gene silencer I revealed that the consensus sequence for ht $\beta$ binding contains 9 nucleotides. This consensus sequence is centered with a reversely oriented CACCC box that was first 
characterized as an important promoter element for globin gene expression (10). The CACCC/GGGTG sequence is necessary for ht $\beta$ protein binding (Fig. 4). A gel shift assay analysis of CACCC/GGGTG box mutants with the ht $\beta$ protein may be necessary to determine the key nucleotides essential for specific binding. A gel shift assay analysis with the same CACCC/GGGTG-containing probe and nuclear extracts from different cell lines revealed a number of bands. Oligonucleotides representing the binding site of transcription factor Spl can compete with $h t \beta$ for binding to the CACCC box, although the competition is not as efficient as that with CACCC box-containing oligonucleotides (data not shown). This result suggests that the CACCC box-binding proteins may interact with Sp1-binding sites in gene regulatory sequences. No specific band is observed in nuclear extracts from $\mathrm{T}$ cells. Interestingly, an extremely rapidly moving band is detected in nuclear extracts from HeLa cells but not from the three types of hematopoietic cells. Whether this CACCC box-binding protein can regulate epithelial cell-specific gene expression is not known. The question of possible different forms of ht $\beta$ that can regulate gene expression is unanswered at this time. Also, a gel shift assay analysis of the CACCC-containing probe with either in vitro-translated protein from a full-length ht $\beta$ cDNA or cell nuclear extracts may tell us which band in the gel shift assay with nuclear extracts corresponds to the ht $\beta$ protein encoded by the gene that we have cloned.

For determination of how many genes are possibly regulated by the ht $\beta$ protein, different TCR genes were analyzed for CACCC/GGGTG boxes. An examination of sequence information from 14 mouse $V \beta$ and 5 human $V \beta$ gene promoters $(1,45)$ revealed that most of the V $\beta 8$ family members of both humans and mice contain the GGGTG box.

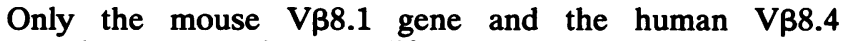
pseudogene contain a modified GGGTG box. Among the other V $\beta$ members examined, only the mouse V $\beta 7$ gene contains a GGGTG box. It is clear that there must be other transcription factors important for TCR expression, since many V $\beta$ genes do not have CACCC/GGGTG box-binding sites. In addition to $V \beta$ genes, other TCR regulatory sequences also contain CACCC/GGGTG boxes, including TCR $\alpha$ and $\beta$ enhancers of both humans and mice $(18,22,28$, 52), and mouse TCR $\alpha$ gene silencers I and II (53). TCR silencer I has four continuous repeats of the GGGTG box and one CACCC box. A functional analysis is necessary to determine whether these CACCC/GGGTG boxes bind to transcription factors and activate gene expression. The CACCC box is not found in the TCR $\gamma$ enhancer (25). Although there is a CACCC box in the TCR $\delta$ enhancer, a DNase I footprinting assay revealed no binding activity at that site (39). Sequences flanking the CACCC box may provide specificity for ht $\beta$ binding in $T$-cell nuclear extracts. An approach to studying the specificity of ht $\beta$ binding to TCR sequences would include examining the ability of the ht $\beta$-binding site in the V $\beta 8.1$ promoter to compete for the binding site in the $\alpha$ gene silencer. We believe that the ht $\beta$ protein may act as an activator for TCR gene expression by binding to the CACCC/GGGTG boxes in the TCR $\alpha$ gene silencer to reverse the silencing activity in $\alpha \beta$ T cells. A comparison of ht $\beta$ gene expression in $\alpha \beta$ T cells versus $\gamma \delta \mathrm{T}$ cells may provide important insight into the regulation of TCR genes during ontogeny.

In addition to those in TCR genes, CACCC/GGGTG boxes first were described in the globin gene promoter and later were found in regulatory sequences of many genes. Most of these CCCAC/GGGTG boxes are functional in the transcriptional activation of these genes. The orientation of the CACCC/GGGTG boxes may not have much influence on transcription (44). Deletion of the ht $\beta$-binding site, which has a CACCC/GGGTG box in it, dramatically reduces transcriptional activity, while the addition of five repeats of the CACCC box to the deletion-containing VB8.1 promoter results in the restoration of transcriptional activity. The results clearly show that the CACCC box is very important for efficient transcription of the VB8.1 promoter. Although there is a CACCC box in the SV40 enhancer, it is not important for transcription in this system. Plasmid $\mathrm{p} \triangle \mathrm{V} \beta 8.1 \mathrm{CAT}$, which has a deletion of the CACCC box in the V8B8.1 promoter but carries the CACCC box in the SV40 enhancer, only expresses basal transcriptional activity (Fig. 6). One study has shown that the upstream CACCC box in the human $\beta$-globin gene promoter is unable to bind the CACCC factor, in contrast to the strong effect of the proximal CACCC box on globin gene transcription. A DNase I footprinting assay analysis (data not shown) indicates that ht $\beta$ binds to the four continuous GGGTG boxes in mouse $\alpha$ gene silencer I very well but that no significant binding to the CACCC box located 101 nucleotides away is observed. The sequences flanking the CACCC box may have a significant effect on its ability to bind transcription factors. Factors that bind to the flanking sequences may influence the interaction between the CACCC box and its binding protein.

The importance of the CACCC box in gene transcription was first shown in a study of the $\beta$-globin promoter. The $\mathrm{C} \rightarrow \mathrm{T}$ transition at the first position of the CACCC box in the $\beta$-globin promoter strongly decreased transcription (10). A CACCC box mutation in the slow/cardiac troponin $\mathrm{C}$ gene enhancer also resulted in an approximately $90 \%$ reduction of transcription relative to that observed with the wild-type enhancer (36). Similar results were obtained for the mouse porphobilinogen deaminase gene (37), the human 7S K RNA gene (26), and GATA-1 gene promoters (49). The function of the CACCC box in other TCR genes has yet to be determined. The cloning of the ht $\beta$ gene will allow further study of the transcriptional regulation of other genes by a CACCC box-binding protein. Another interesting aspect of the CACCC box is that a mutation at this binding site can cause disease. A mutation at position $-87(C \rightarrow T$ or $C \rightarrow G)$ in the CACCC box of the globin promoter greatly decreases the transcriptional activity of the $\beta$-globin gene, and a natural mutation at that position has been shown to cause thalassemia $(15,30)$. Our study also shows that the CACCC box is important for TCR gene transcription. A mutation in the CACCC box of the TCR promoter may cause the inefficient expression of certain $V \beta$ genes, therefore influencing the immune response carried out by a population of $T$ cells that normally use that $\mathrm{V} \beta$ gene product together with a particular $\mathrm{V} \alpha$ gene product to recognize the major histocompatibility complex molecule and foreign peptide.

The ht $\beta$ protein can reproducibly counteract the silencing activity of mouse TCR $\alpha$ gene silencer I (Fig. 8). The antagonizing activity of the ht $\beta$ protein for the TCR $\alpha$ gene silencer may have interesting implications for TCR gene expression in $\alpha \beta$ and $\gamma \delta \mathrm{T}$ cells. We speculate that perhaps in $\gamma \delta \mathrm{T}$ cells, either the ht $\beta$ protein is not expressed or the $\mathrm{ht} \beta$ protein is functionally different from that in $\alpha \beta \mathrm{T}$ cells, possibly because of (i) the posttranslational modification of the ht $\beta$ protein, (ii) the accessibility of TCR $\alpha$ gene silencer sequences to the ht $\beta$ protein, since $\alpha \beta$ and $\gamma \delta \mathrm{T}$ cells may have different chromatin structures at the $\alpha / \delta$ locus, (iii) the concentration of the $h t \beta$ protein, or (iv) the combinatorial interaction of the ht $\beta$ protein with different general transcrip- 
tion factors. The CACCC boxes in the TCR $\alpha$ gene silencer may be inaccessible to the ht $\beta$ protein for any one of the above-listed reasons, resulting in the silencing of the $\alpha$ locus in $\gamma \delta \mathrm{T}$ cells. On the contrary, in $\alpha \beta \mathrm{T}$ cells, the actively expressed ht $\beta$ protein may bind to the CACCC boxes in both silencers I and II, resulting in the relief of silencing activity and leading to the expression of the TCR $\alpha$ gene. The current study, however, does not provide definite evidence that the ht $\beta$ protein is the key player affecting $\alpha \beta$ versus $\gamma \delta$ TCR gene expression. The details of how the ht $\beta$ protein and other transcription factors are involved in the TCR $\alpha$ gene activity of $\alpha \beta$ and $\gamma \delta \mathrm{T}$ cells may help to explain the process of differentiation of these two populations of $T$ cells. In addition, how the interactions between the ht $\beta$ protein and other transcription factors provide specificity in different gene systems will be particularly interesting.

\section{ACKNOWLEDGMENTS}

We thank K. C. Cheng, Peter Mathisen, Sally Orr, Wenron Qiu, David Wang, Kangsheng Wang, and Ebrahim Zandi for technical advice during the course of this work. We also thank Jeffrey Leiden for critical comments on this work. We are grateful to Peter Mathisen and Erich Strauss for comments on the manuscript.

This work was supported in part by National Institutes of Health grant HG00356. Y.W. also thanks the K. C. Wong Education Foundation, Ltd., Hong Kong, for financial aid.

\section{REFERENCES}

1. Anderson, S. J., H. S. Chou, and D. Y. Loh. 1988. A conserved sequence in the T-cell receptor $\beta$-chain promoter region. Proc. Natl. Acad. Sci. USA 85:3551-3554.

2. Ausubel, F. M., R. Brent, R. E. Kingston, D. D. Moore, J. G. Seidman, J. A. Smith, and K. Struhl. 1987. Current protocols in molecular biology. John Wiley \& Sons, Inc., New York.

3. Aviv, H., and P. Leder. 1972. Purification of biologically active globin messenger RNA by chromatography on oligothymidylic acid-cellulose. Proc. Natl. Acad. Sci. USA 69:1408-1412.

4. Beckmann, H., L.-K. Su, and T. Kadesch. 1990. TFE3: a helix-loop-helix protein that activates transcription through the immunoglobulin enhancer $\mu \mathrm{E} 3$ motif. Genes Dev. 4:167-179.

5. Bohmann, D., T. J. Bos, A. Admon, T. Nishmura, P. K. Vogt, and R. Tjian. 1987. Human proto-oncogene C-Jun encodes a DNA-binding protein with structural and functional properties of transcription factor AP-1. Science 238:1386-1392.

6. Chien, Y. H., D. M. Becker, T. Lindsten, M. Okamura, D. I. Cohen, and M. M. Davis. 1984. A third-type of murine T-cell receptor gene. Nature (London) 312:31-35.

7. Chien, Y. H., M. Iwashima, K. B. Kaplan, J. F. Elliott, and M. M. Davis. 1987. A new T-cell receptor gene located within the alpha locus and expressed early in T-cell differentiation. Nature (London) 327:677-682.

8. Chien, Y. H., M. Iwashima, D. A. Wettstien, K. B. Kaplan, J. F. Elliott, W. Born, and M. M. Davis. 1987. T-cell receptor delta gene rearrangements in early thymocytes. Nature (London) 330:722-727.

9. Diamond, D. J., F. B. Nelson, and E. L. Reinherz. 1989. Lineage-specific expression of a $\mathbf{T}$ cell receptor variable gene promoter controlled by upstream sequences. J. Exp. Med. 169:1213-1231.

10. Dierks, P., A. van Ooyen, M. D. Cochran, C. Dobkin, J. Reiser, and C. Weissman. 1983. Three regions upstream from the Cap site are required for efficient and accurate transcription of the rabbit $\beta$-globin gene in mouse 3T6 cells. Cell 32:695-706.

11. Dingwall, C., and R. A. Laskey. 1986. Protein import into the cell nucleus. Annu. Rev. Cell Biol. 2:367-390.

12. Fan, C.-M., and T. Maniatis. 1990. A DNA-binding protein containing two widely separated zinc finger motifs that recognize the same DNA sequence. Genes Dev. 4:29-42.

13. Fujita, T., H. Shibuya, T. Ohashi, K. Yamanishi, and T. Taniguchi. 1986. Regulation of the human interleukin-2 gene: functional DNA sequence in the $5^{\prime}$ flanking region for gene expression in activated T lymphocytes. Cell 46:401-407.

14. Galas, D. J., and A. Schmitz. 1978. DNase footprinting: a simple method for the detection of protein-DNA binding specificity. Nucleic Acids Res. 5:3157-3171.

15. Giglioni, B., P. Comi, A. Ronchi, R. Mantovani, and S. Ottolenghi. 1989. The same nuclear proteins bind the proximal CACCC box of the human $\beta$-globin promoter and a similar sequence in the enhancer. Biochem. Biophys. Res. Commun. 164:149-155.

16. Giniger, E., S. M. Varnum, and M. Ptashne. 1985. Specific DNA binding of GAL4, a positive regulatory protein of yeast. Cell 40:767-774

17. Gorman, C., L. Moffat, and B. Howard. 1982. Recombinant genomes which express chloramphenicol acetyltransferase in mammalian cells. Mol. Cell. Biol. 2:1044-1051.

18. Gottschalk, L. R., and J. M. Leiden. 1990. Identification and functional characterization of the human T-cell receptor $\beta$ gene transcriptional enhancer: common nuclear proteins interact with the transcriptional regulatory elements of the T-cell receptor $\alpha$ and $\beta$ genes. Mol. Cell. Biol. 10:5486-5495.

19. Govindan, M. V., F. Pothier, S. Leclerc, R. Palaniswami, and M. Xie. 1991. Human glucocorticoid receptor gene promoterhomologous down regulation. J. Steroid Biochem. Mol. Biol. 40:317-323.

20. Hedrick, S. M., E. A. Nielsen, J. Kavaler, D. I. Cohen, and M. M. Davis. 1984. Sequence relationships between putative T-cell receptor polypeptides and immunoglobulins. Nature (London) 308:149-153.

21. Ho, I.-C., N. K. Bhat, L. R. Gottschalk, T. Lindsten, C. B. Thompson, T. K. Papas, and J. M. Leiden. 1990. Sequencespecific binding of human Ets-1 to the $\mathrm{T}$ cell receptor gene enhancer. Science 250:814-818.

22. Ho, I.-C., L.-H. Yang, G. Morle, and J. M. Leiden. 1989. A T-cell specific transcriptional enhancer element $3^{\prime}$ of $\mathrm{C} \alpha$ in the human T-cell receptor locus. Proc. Natl. Acad. Sci. USA 86:6714-6718.

23. Hoey, T., and M. Levine. 1988. Divergent homeobox proteins recognize similar DNA sequences in Drosophila. Nature (London) 332:858-861.

24. Hope, I. A., and K. Struhl. 1985. GCN4 protein, synthesized in vitro, binds HIS3 regulatory sequences: implication for general control of amino acid biosynthetic genes in yeast. Cell 43:177188.

25. Kappes, D. J., C. P. Browne, and S. Tonegawa. 1991. Identification of a T-cell-specific enhancer at the locus encoding T-cell antigen receptor $\gamma$ chain. Proc. Natl. Acad. Sci. USA 88:2204 2208.

26. Kleinert, H., R. Assert, and B.-J. Benecke. 1991. A single base pair deletion from the inactive octamer-like motif of the 7S K RNA distal sequence element brings full functionality in vivo. $\mathrm{J}$. Biol. Chem. 266:23872-23877.

27. Kranz, D. M., H. Saito, M. Heller, Y. Takagaki, W. Haas, H. N. Eisen, and S. Tonegawa. 1985. Limited diversity of the rearranged T-cell gene. Nature (London) 313:752-755.

28. Krimpenfort, P., R. de Jong, Y. Uematsu, Z. Dembic, S. Ryer, H. von Boehmer, M. Steinmetz, and B. Berns. 1988. Transcription of $T$ cell receptor $\beta$-chain gene is controlled by a downstream regulatory element. EMBO J. 7:745-750.

29. Kronenberg, M., G. Siu, L. Hood, and N. Shastri. 1986. The molecular genetics of the T-cell antigen receptor and T-cell antigen recognition. Annu. Rev. Immunol. 4:529-591.

30. Kulozik, A. E., A. Bellan-Koch, S. Bail, E. Kohne, and E. Klenhauer. 1991. Thalassemia intermedia: moderate reduction of $\beta$-globin gene transcription activity by a novel mutation of the proximal CACCC promoter element. Blood 77:2054-2058.

31. Ma, J., and M. Ptashne. 1987. A new class of yeast transcriptional activators. Cell 51:113-119.

32. Maeda, M., K.-I. Oshuma, S. Tamura, S. Kaya, S. Mahood, M. A. Reuben, L. S. Lasater, G. Sachs, and M. Futai. 1991. The rat $\mathrm{H}^{+} / \mathrm{K}^{+}$-ATPase $\beta$ subunit gene and recognition of its control region by gastric DNA binding protein. J. Biol. Chem. 266: 21584-21588. 
33. Maniatis, T., E. F. Fritsch, and J. Sambrook. 1989. Molecular cloning: a laboratory manual. Cold Spring Harbor Laboratory, Cold Spring Harbor, N.Y.

34. McDougall, S., C. L. Peterson, and K. Calame. 1988. A transcriptional enhancer $3^{\prime}$ of $C \beta 2$ in the $T$ cell receptor $\beta$ locus. Science 241:205-208.

35. Miller, J., A. D. McLachlan, and A. Klug. 1985. Repetitive zinc-binding domains in the protein transcription factor IIIA from Xenopus oocytes. EMBO J. 4:1609-1614.

36. Parmacek, M. S., A. J. Vora, T. Shen, E. Barr, F. Jung, and J. M. Leiden. 1992. Identification and characterization of a cardiac-specific transcriptional regulatory element in the slow/ cardiac troponin C gene. Mol. Cell. Biol. 12:1967-1976.

37. Porcher, C., G. Pitiot, M. Plumb, S. Lowe, H. de Verneuil, and B. Grandchamp. 1991. Characterization of hypersensitive sites, protein binding motifs, and regulatory elements in both promoters of the mouse porphobilinogen deaminase gene. J. Biol. Chem. 266:10562-10569.

38. Ptashne, M. 1988. How eukaryotic transcriptional activation works. Nature (London) 335:683-689.

39. Redondo, J. M., S. Hata, C. Brocklehurst, and M. S. Krangel. 1990. A T cell-specific transcriptional enhancer within the human T cell receptor $\delta$ locus. Science 247:1225-1229.

40. Royer, H. D., and E. L. Reinherz. 1987. Multiple nuclear proteins bind upstream sequences in the promoter region of a T-cell receptor beta-chain variable region gene: evidence for tissue specificity. Proc. Natl. Acad. Sci. USA 84:232-236.

41. Saito, H. D., M. Kranz, Y. Takagaki, A. C. Hayday, H. N. Eisen, and S. Tonegawa. 1984. Complete primary structure of a heterodimeric T-cell receptor deduced from cDNA sequence. Nature (London) 309:757-762.

42. Saito, H. D., M. Kranz, Y. Takagaki, A. C. Hayday, H. N. Eisen, and S. Tonegawa. 1984. A third rearranged and expressed gene in a clone of cytotoxic T lymphocytes. Nature (London) 312: $36-40$.

43. Schreiber, E., P. Matthias, M. M. Muller, and W. Schaffner. 1988. Identification of a novel lymphoid specific binding protein (OTF-2B) by proteolytic clipping bandshift assay (PCBA). EMBO J. 7:4221-4229.

44. Schule, R., M. Muller, H. Otsuka-Murakami, and R. Renkawith. 1988. Cooperativity of the glucocorticoid receptor and the
CACCC-box binding factor. Nature (London) 332:87-90.

45. Siu, G., E. C. Strauss, L. Lai, and L. Hood. 1986. Analysis of a human V $\beta$ gene subfamily. J. Exp. Med. 164:1600-1614.

46. Struhl, K. 1988. The Jun oncoprotein, a vertebrate transcription factor, activates transcription in yeast. Nature (London) 332: 649-650.

47. Studier, F. W., A. H. Rosenberg, J. J. Dunn, and J. W. Dubendorfi. 1990. Use of T7 RNA polymerase to direct the expression of cloned genes. Methods Enzymol. 185:60-89.

48. Treisman, J., and C. Desplan. 1989. The products of the Drosophila GAP genes hunchback and kruppel bind to the hunchback promoters. Nature (London) 341:335-337.

49. Tsai, S.-F., E. Strauss, and S. H. Orkin. 1991. Functional analysis and in vivo footprinting implicate the erythroid transcription factor GATA-1 as a positive regulator of its own promoter. Genes Dev. 5:919-931.

50. Vinson, C. R., K. L. Lamarco, P. E. Johnson, W. H. Landschulz, and S. L. McKnight. 1988. In situ detection of sequence-specific DNA binding activity specified by a recombinant bacteriophage. Genes Dev. 2:801-806.

51. Waterman, M. L., and K. A. Jones. 1990. Purification of TCF-1 $\alpha$, a T-cell-specific transcription factor that activates the $\mathrm{T}$-cell receptor $\mathrm{C} \alpha$ gene enhancer in a context-dependent manner. New Biol. 2:621-636.

52. Winoto, A., and D. Baltimore. 1989. A novel, inducible and $T$-cell specific enhancer located at the $3^{\prime}$ end of the $T$ cell receptor $\alpha$ locus. EMBO J. 8:729-733.

53. Winoto, A., and D. Baltimore. 1989. $\alpha \beta$ lineage-specific expression of the $\alpha \mathrm{T}$ cell receptor gene by nearby silencers. Cell 59:649-655.

54. Winoto, A., S. Mjolsness, and L. Hood. 1985. Genomic organization of the gene encoding the mouse T-cell receptor $\alpha$ chain. Nature (London) 316:832-836.

55. Xu, M., and J. Stavnezer. 1992. Regulation of transcription of immunoglobulin germ-line $\gamma 1$ RNA, analysis of the promoter/ enhancer. EMBO J. 11:145-155.

56. Yanagi, Y., Y. Yoshikai, K. Leggette, S. Clark, I. Aieksander, and T. W. Mak. 1984. A human T cell-specific cDNA clone encodes a protein having extensive homology to immunoglobulin chains. Nature (London) 308:145-149. 